\title{
artículos
}

\section{Música en honor de los Santos Patronos de Málaga Ciriaco y Paula}

\author{
Antonio Tomás del Pino Romero \\ Investigador vinculado a la UMA
}

RESUMEN

El culto y la devoción que la ciudad de Málaga ha tributado a sus patronos san Ciriaco y santa Paula a través de la historia se reflejan en la música litúrgica en su honor que se custodia en el Archivo de la Catedral de Málaga. Rituales, fiestas, procesiones y músicos como Sanz, Iribarren, Torrens u Ocón conforman estas celebraciones en las que la música era parte fundamental.

PALABRAS CLAVE: Catedral de Málaga/ San Ciriaco/ Santa Paula/ Música religiosa/ Órgano/ Música barroca/ Patronos/ Iribarren/ Torrens/ Ocón.

Music in honour for Patron Saints of Málaga Ciriaco and Paula

ABSTRACT

The cult and devotion that the city of Malaga had offered to their saint patronesses Ciriaco and Paula throughout the history are reflected in the liturgical music in their honor which is preserved in the Archive of Malaga Cathedral. Rituals, feasts, processions and musicians like Sanz, Iribarren, Torrens or Ocon are part of these celebrations in which music was an essential part.

KEY WORDS: Cathedral Of Málaga/ Saint Ciriaco/ Saint Paula/ sacred music/ organs/ Baroque music/ Patron saints/ Iribarren/ Torrens/ Ocon.

$1^{\circ}$ La música conservada en el archivo de la S. I. Catedral de Málaga.

La más valiosa documentación para conocer el esplendor que la devoción a los Santos Patronos de Málaga conoció en la segunda mitad del s. XVIII, además de las anotaciones a ellos referidas que podemos encontrar en las Actas Capitulares de nuestro primer Templo y de las que tendremos ocasión de dar noticia más adelante, es la ingente cantidad de piezas musicales que tienen dedicados y que se encuentran en el riquísimo Archivo de Música de la Catedral. Pero, además, tenemos un magnífico testimonio para conocer el grado de solemnidad con que se celebraba la fiesta en honor de San Ciriaco y Santa Paula en esta época. Se trata del "Quaderno de las obligaciones que deben cumplir los Músicos de voz, Ministriles y demás Instrumentistas de la Capilla de Música de esta Santa Iglesia Catedral de Málaga (...) según lo que consta de las Tablas de su sacristía (...) hasta este año de 1770'”. Por lo que podemos deducir a

* DEL PINO ROMERO, Antonio Tomás: "Música en honor de los Santos Patronos de Málaga Ciriaco y Paula", en Boletín de Arte n 32-33, Departamento de Historia del Arte, Universidad de Málaga, 2011-2012, págs. 177 206. Fecha de recepción: Julio de 2010.

1 Se trata de un pequeño cuaderno de apenas una treintena de páginas impreso en 1770 en Málaga por el impresor de la Dignidad Episcopal y de la Santa Iglesia Catedral. 
2. Tradiderunt Corpora Sua. Francisco Sanz. Principios del siglo XVIII.

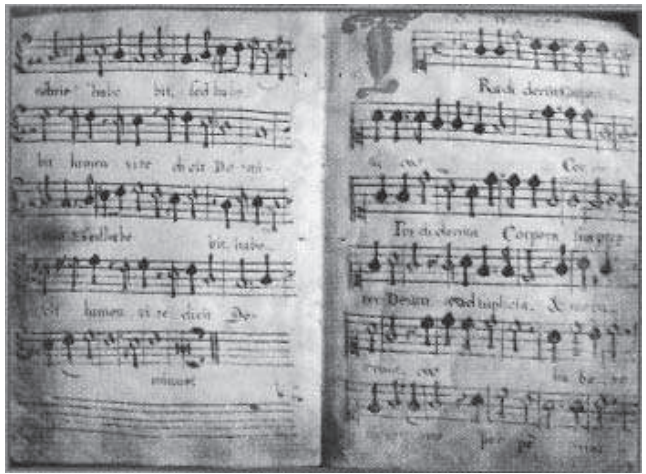

y fegundas Vísperas, y Maytines, como al numero $l^{3}$. La Prima se empieza a las siete. La Misa es de Facistol, con motete. En la Procesion despues de Nona tocan las chirimías, alternando con los Sochantres a ida y vuelta. La Misa es como al num. I con villancicos. Nota Quando esta Festividad cae en la Octava de Corpus, se celebra todo como al num. I: y el dia octavo se hace la Procesion, y la Misa como queda dicho". La procesión claustral incluía una estación en la Capilla de la Encarnación, donde, por otra parte, en el último tercio del s. XVIII, es decir, coincidiendo con el periodo de mayor devoción a estos jóvenes santos, se colocarían las espléndidas imágenes en mármol de los Mártires, obra de Juan de Salazar ${ }^{5}$ (autor también de la imaginería de las cajas de los órganos ${ }^{6}$ ).

Además del día de su festividad, cuyo modus celebrandi acabamos de ver, la música relacionada con los Patronos está presente en eventos tan relevantes como la entrada pública y juramento de los obispos, tal y como prescribe el mismo Quaderno de Obligaciones ${ }^{7}$, hecho que hemos podido constatar en los casos de los siguientes purpurados: Juan de Eulate y Santa Cruz $^{8}$, Luís de Franquis Lasso de Castilla ${ }^{9}$, José Vicente de la Madriz ${ }^{10}$, Alonso Vigil y Cañedo ${ }^{11}$ y Manuel Gómez Salazar ${ }^{12}$. En los

\footnotetext{
3 Por tanto, la máxima solemnidad prevista.

4 Hemos conservado la grafía original.

5 SAURET, T., La Catedral de Málaga, Centro de Ediciones de la Diputación de Málaga, Málaga, 2003, p. 211.

6 PÉREZ DEL CAMPO, L., ROMERO DE TORRES, J. L., La Catedral de Málaga, Everest, 1986, p. 30

7 Por otra parte, el Quaderno no hace más que explicitar al caso de Málaga refiriéndose a una pieza concreta la prescripción universal que se registra para el Ordo ad recipiendum processionalitar Episcopum, donde se indica claramente que la ceremonia finaliza en esta forma: Deinde cantores cantant Antiphonam et Versus de Sancto Patrono.

8 (A)ctas (C)apitulares de la (C)atedral de (M)álaga (en adelante, A.C.C.M.), 22 de junio de 1745, tomo 37, fols. 365-367.

9 A.C.C.M., 16 de noviembre de 1756 , tomo 37 , fols. $381-383$

10 A.C.C.M., 17 de febrero de 1801 , tomo 58 , fols. $466-467$

11 A.C.C.M., 30 de abril de 1815 , tomo 62 , fols. $407-409$.

12 A.C.C.M., 10 de agosto de 1879 , tomo 72 , fols. 206-207.
} 


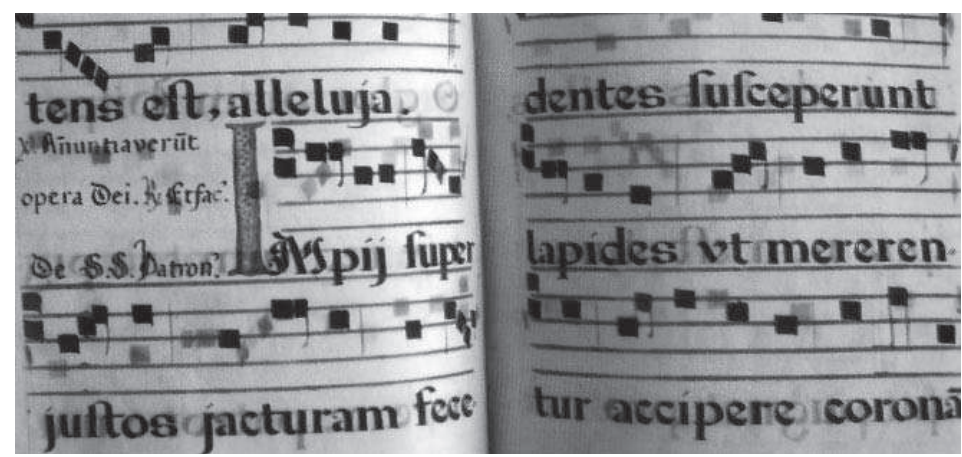

3. Impii Super Iustos. Juan Francés de Iribarrén. Antífona dedicada a los Santos Patronos propia de la Catedral de Málaga. Principios del siglo XVIII.

tres primeros, se puede encontrar, sin registrar diferencias entre ellos, la siguiente anotación: "en el interim cantó la Capilla de Música un Villancico y la Antífona de los Santos Patronos"13, mientras que en los dos siguientes se lee: “...dijo en él la oración de la Virgen y de los Santos Patronos, e inmediatamente se colocó en medio del altar y cantó Sit nomen Domine benedictum, y dio la bendición episcopal".

Retrotrayéndonos a los albores de la recién reconquistada Málaga y los primeros pasos de su cabildo eclesiástico, la primera referencia que encontramos en las Actas Capitulares donde se informa de algún tipo de actividad que podamos relacionar con lo musical en el culto a los Santos Patronos es de 1515, cuando se reparten 2190 maravedíes a los beneficiados asistentes al mismo ${ }^{14}$. Años más tarde, en 1569, el cabildo se propone aumentar la solemnidad de tal celebración, ya que: "por cuanto en otras Ciudades el dia del Patron dellas suelen solenizar su fiesta, acordaron que se hable a su señoria para que el dia de sant Ciriaco y Paula Patronos desta Çiudad se haga procesion a su iglesia de los martyres, como antes se solia hazer"15.

El sábado 16 de junio de 1582 va a tener lugar una reunión del cabildo, al que llegan a asistir tanto el obispo como la Justicia y Regimiento de la ciudad:

"Primeramente trataron los dichos señores de cómo la justicia y regimiento desta ciudad han acordado con consentimiento de su señoria Illustrisima de guardar

13 En el Quaderno de las obligaciones... se especifica que se cante el Impii super iustos, pero no viene esta advertencia en el día de los Patronos, sino en la entrada de obispos, como indicamos arriba. Encontramos dos piezas con dicho título: la antífona gregoriana, que se encuentra en el cantoral 75 , fol. $64 \mathrm{v}$. y la compuesta por Iribarren, de la que hablaremos más adelante. El Quaderno dice que se cante a contrapunto, textura en que está compuesto el motete de Iribarren.

14 A.C.C.M., 24 de junio de 1515, libro 5, fol. 146 vto

15 A.C.C.M., 30 de junio de 1569, libro 11, fol. 305 


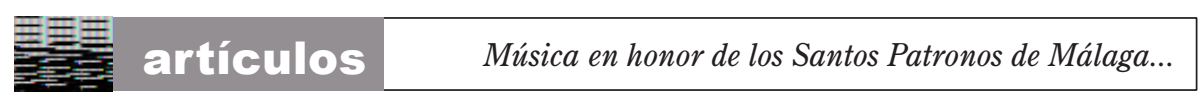

perpetuamente en esta ciudad $y$ arrabales el dia de la festividad de los gloriosos martires ziriaco y Paula Virgen, Patronos y naturales desta ciudad. Por tanto que se platique $y$ determine si por parte desta iglesia y clero se hara el dicho voto o no $y$ aviendose votado y platicado sobre ello, quedo acordado que aceptando su señoria Illustrisima por parte de la ciudad el dicho voto, que señor chantre como presidente haga en manos de su señoria Illustrisima el mismo voto en nombre desta iglesia y clero desta ciudad.

Que los que dixeren la letania vayan descubiertas las cabezas

Yten acordaron los dichos señores que los que dixeren la letania por la yglesia y fuera Della la canten sin bonetes y no de otra manera.

Su señoria Illustrisima vino a cabildo.

Salieron del cabildo todos los dichos señores y luego boluieron a el acompañando al Illustrisimo $y$

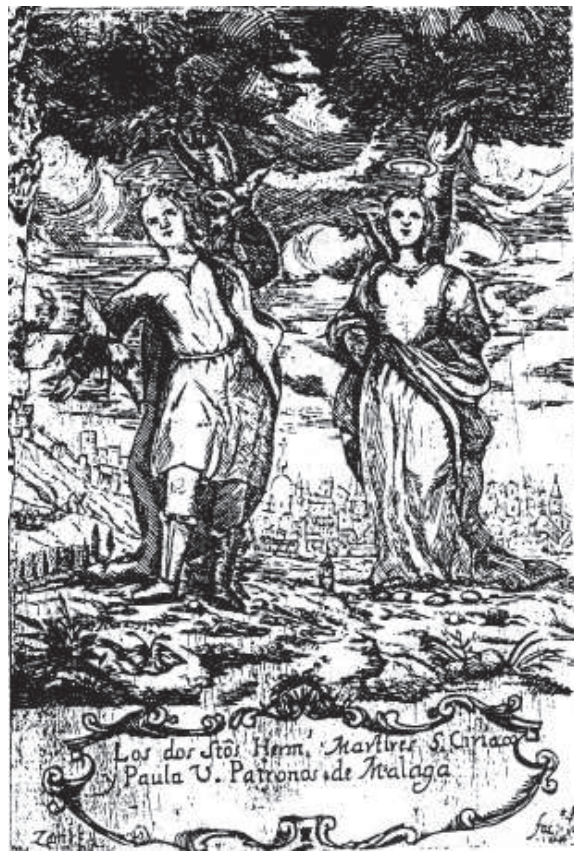

4. Santos Ciriaco y Paula. Grabado popular. Siglo XVIII.

Reuerendisimo señor Don FranÇisco Pacheco de Cordoua obispo de Malaga y del consejo de su majestad, y asi juntos con consentimiento y voluntad de los dichos señores ordenó y hizo su señoria Illustrisima el aucto capitular siguiente.

Acuerdo de Malaga para que dos Regidores hagan voto en nombre de la ciudad en manos de su señoria Illustrisima de guardar perpetuamente el dia de los gloriosos Martires ziriaco y Paula virgen Patronos y naturales de Esta ciudad.

La ciudad acordo que porque estaua cometido a los señores Pedro de Madrid mampaso y comendador Diego de torres de la vega para que tratasen con los señores dean y cabildo desta santa iglesia de dar orden como celebrar con mucha solemnidad la festividad de los santos Cyriaco y Paula patronos desta ciudad, y que para Ello se hiziese y fundase una cofradía con las constituciones y capitulaciones que les pareciesen convenir y que el beneficio de las limosnas que se cojiesen pareció entonzes que se debia atribuir para remediar necesidades de pobres de la carcel, lo qual paresce que se trato, y por estar entonzes ausente el Illustrisimo de Malaga no vino en Effecto, y tambien porque después aca salio deste cabildo el señor comendador Diego de torres, y asi sea diferido para se hazer con mas acuerdo. $Y$ 
ahora entendiendo la ciudad lo mucho que ymporta que se haga y se effectue lo comenzado, se acuerda se hagan dos bultos de plata armados sobre madera de vna vara en alto de los bien aventurados santos para los lleuar en hombros en sus andas aquel dia suyo en procesión, y que por ciudad vayan en procesión los caballeros de El ayuntamiento y que lleuen su zera y aquel dia se suplique a su señoria del señor obispo mende que se guarde como se haze el dia de sant luis y la ciudad lo vote asi, con que no obligue a culpa, sino solamente a culpa de dineros para que la ejecuten las Justicias, aplicada la mitad para el denunciador y la otra mitad para la cofradía, y con que se entienda que en el campo puedan entender en sus labores, porque solo sea de guardar en la ciudad y sus arrabales, y no se entienda sea fiesta de guardar en quanto para correr toros, porque esto se pueda hazer en coso cercado, y para hazer los capitulos que convengan de constituciones de la dicha cofradía con aprouacion del dicho señor obispo. Y se nombra por diputado juntamente con el señor Pedro de Madrid mampaso al señor Pedro Rodríguez del campo, Regidor. Y para ympetrar cualesquier indulgencias y se libren todo lo que dixeren los dichos caballeros diputados, asi para hazer los bultos de plata de los dichos santos como para lo demas e se dé libranza en forma por lo que dieren firmado.

$Y$ al fin del dicho cabildo auia los nombres y firmas siguientes (...)

Yten su señoria Illustrisima y los dichos señores Dean y cabildo acordaron que las ymagines de los gloriosos martires Sant ziriaco y Paula virgen, Patronos desta ciudad, vayan El dia de su festividad en la procesion que se haze a su parrochia entre los señores desta santa iglesia y detrás de la cruz Della, attento a que son Patronos y naturales desta ciudad y que la dicha procesion se haze en honra y reuerencia suya"16.

El resto de la documentación capitular que hemos podido consultar da cuenta del grado de solemnidad con que se celebraba a los Santos Patronos toda vez que, por ejemplo, a la hora de celebrar en el Colegio de la Compañía la canonización de San Estanislao de Kotska y San Luís Gonzaga en 1727, se dice que se haga "en la forma que reserva la fiesta de los Santos Patronos de la Ciudad"17. También en 1735, y después de haber realizado una procesión a la iglesia de la Victoria con las imágenes de los patronos ad petendam pluviam, y habiéndose obtenido por la intercesión de la Virgen tan implorado favor, propone el Sr. Deán que, en acción de gracias, se traslade la imagen de la Virgen de los Reyes al altar mayor donde "con los Santos Patronos se cantase una Misa de Gracias con la mayor solemnidad"18.

Con respecto a la presencia del rey de los instrumentos en la iglesia parroquial de los Mártires, la primera noticia que hemos encontrado es de 1668, año en que el organero granadino Diego Paniagua reside en Málaga y se compromete a aderezar

16 A.C.C.M., 16 de junio de 1582, libro 13, fols. 127-130.

17 A.C.C.M., 11 de noviembre de 1727 , tomo 43 , fol. 731 vto.

18 A.C.C.M., 3 de marzo de 1735 , tomo 44 , s/f. 
y reedificar el órgano de la parroquial de los Mártires, lo cual significa existía ya un órgano por entonces, pero en mal estado o viejo a juzgar por la envergadura de las obras que el organero afirma que necesita:

"Se ha de poner en tono de cantores que es el tono que hoy se practica en todas las catedrales, por ser ajustado a villancicos. Se han de hacer los cinco caños principales del castillo mayor de nuevo, abriéndolos y labrando las planchas, haciéndoles pies y lenguas de nuevo. Se ha de reparar y soldar y desabollar toda la cañutería de la fachada de dicho órgano y se ha de hacer en el llano y las demás misturas muchas cañuterías, por cuanto le falta, y la que el dicho tiene hoy está muy estragada y mucha de ella no ha de servir, y la que estuviere para poder servir se ha de poner tan corriente como si de nuevo se hiciera.

Se ha de hacer compostura nueva muy brillante, a lo que hoy se practica, $y$ se ha de hacer un secreto nuevo, de la mejor madera que se hallare, con sus capas y registros partidos y el teclado por la parte de adelante del dicho órgano con sus movimientos de registradora.

Se ha de enhilar el juego de barretas nuevas, engarzadas muy fuertes en hilo de latón muy fuertes. Se han de hacer tres fuelles nuevos de siete cuartas de largo, y tres cuartas y cuatro dedos de ancho las tablas principales y han de ser las dichas tablas del mejor pino que se hallare, con sus juegos de álamo blanco o de chopo, y los dichos juegos de tablas muy bien embarrotadas y embisagradas, y los dichos juegos han de estar forrados por de dentro en papel de marca mayor, porque el viento en ningún tiempo se vaya por algún poro de la madera, y por defuera en baldres de guantería forrados dos veces, muy fuertes.

Hanse de hacer alzaprima y puente y cama de dichos fuelles de la mejor madera que se hallare y demás dura con sus aldabas y medios gonces de hierro, muy durables, y que un muchacho desentone muy fácilmente. Se han de echar celosías nuevas por la parte de atrás de dicho órgano, de modo que no puedan sacar los muchachos los caños.

Se ha de reparar el conducto por donde va el aire de los dichos fuelles al órgano; se ha de limpiar la caja y repararla si le falta alguna cosa.

Este dicho aderezo pulizando los materiales y costas son muy grandes y no se puede hacer menos de 600 ducados, haciéndolo con toda perfección y cuidado a satisfacción de cuantos maestros tuviere la Andalucía, y que si no lo valiere, que no se me de la cantidad que me restare, lo cual me obligaré por escritura"19.

19 LLORDÉN, A., Notas de los maestros organeros que trabajaron en Málaga, Anuario Musical, vol. XIII. Barcelona, 1958, págs. (179-181) 13-15. 
El mayordomo de la iglesia parroquial de los Mártires, lic. Don Juan de la cruz dio testimonio de que el maestro organero había examinado el citado órgano para ver los reparos que necesitaba y ratifica en todo lo consignado en dicho memorial. Por tanto, eleva al señor obispo una súplica a fin de que ordene al mayordomo general lo concierte, porque el órgano que había al presente no se usaba dado el mal estado en que se encontraba. El señor obispo, Fr. Alonso de Santo Tomás, por medio de su secretario Mateo de Murga y Quevedo, mandó en 13 de junio de 1668, al lic. Don Juan Muñoz de Arcila, que desempeñaba el cargo de mayordomo de las fábricas, concertara el trabajo que el citado maestro, asunto que se demoró hasta el 31 de agosto, día en que se otorgó escritura en que Diego de Paniagua se obliga "...a aderezar el dicho órgano comenzando desde el día postrero del mes de septiembre de este presente año de 1668 y lo dará acabado con toda perfección, sin que le falte cosa alguna dentro de dos meses (...) y después de acabado ha de ver el dicho órgano el maestro que nombrare su excelencia para que reconozca si está corriente y con toda perfección, el cual dicho maestro se ha de traer a mi costa de la parte donde estuviere y si declarare que tiene algún defecto o imperfección lo tengo que rectificar hasta dejarlo a satisfacción del dicho maestro, por todo lo cual las dichas fábricas me tienen que dar y pagar quinientos ducados en reales de moneda de vellón en esta manera, los doscientos que ahora de presente recibo de mano del lic. D. Juan Muñoz de Arcila y los otros 150 ducados luego que este hecha la mitad de la obra, y los restantes luego que esté terminada"20.

Este mismo órgano del s. XVII vuelve a tener necesidad de una puesta a punto ya que en junio de 1713 en sesión capitular "leyóse un Memorial de D. Sebastián Alejo, Maestro de hacer Organos, en que dice haber aderezado el de la Parroquia de los Santos Mártires de esta Ciudad con orden del Sr. Obispo, y empezado el de la Parroquia de San Juan, y pide se aprecie por D. Miguel Conejos, y ofrece hacer equidad de su aprecio y se le mande pagar y proseguir en el que estaba aderezando en la de San Juan y los demás que necesitaren. Y a vista se acordó que el Mayordomo General de Fábricas informe si hubo necesidad de aderezar del que se refiere, y si hay Decreto del Sr. Obispo para ello y qué cantidad ofrecieron los Beneficiados y Curas de los Mártires para ayuda, y en vista se hará providencia"21. En posteriores sesiones del mismo mes se sigue aludiendo a esta cuestión del arreglo del instrumento de los Mártires por el citado organero, disponiéndose que sea el por entonces organista de la Catedral el encargado, como máxima autoridad local en la materia, el que deba pronunciarse sobre la intervención practicada por Sebastián Alejo: "El presente Secretario leyó el Informe que hace el Mayordomo General de Fábrica sobre el Memorial que en el primero del corriente presentó $D$. Sebastián Alejo sobre el aderezo del Organo de la Parroquia de los Santos Mártires de esta Ciudad. Y visto se acordó que el Sr. Racionero D. Miguel Conejos aprecie la mixtura de trompetas que le ha

20 Archivo de protocolos, Escribanía de Juan Esteban Lavado. Cit. en LLORDÉN, op. cit., p. 14 (181).

21 A.C.C.M., 1 de junio de 1713, tomo 40, fol. 218. 
cebado y falta por pagar"22. Justo a los cinco días "El Sr. Deán dijo que habiendo apreciado D. Miguel Conejos la mixtura de trompetas puesta en el Organo de la Parroquia de los Mártires de esta Ciudad en cien pesos, ofreció el Reverendo en darla en la mitad y el Sr. Deán lo apartó en seiscientos reales y declara dicho Conejos queda el Organo muy bien aderezado, y que el Cabildo disponga lo que fuese servido. Y se acordó se libren los seiscientos reales del último aderezo y mixtura de las trompetas y ajustó el Sr. Deán que se le paguen en cuenta al Mayordomo General los veinte reales que tiene pagados del primer aderezo en virtud del Decreto del Sr. Obispo"23. Sin embargo, este arreglo no va a tener una larga duración, por cuanto a finales del mismo año "el Mayordomo General de Fábricas Menores dijo en un Memorial que D. Sebastián Alexos, Maestro de Organos y nombrado para aliñar el de la Parroquia de Santiago, no lo hace con la firmeza que dice, como se ha experimentado también en el que aderezó en el de los Santos Mártires"24.

Junto al arreglo total de la iglesia, que se inaugurará como veremos en junio de 1777 , se procederá a la fábrica de un nuevo órgano en $1766^{25}$, con caja de Diego Robles $^{26}$, sin citarse el organero, aunque sabemos que se trata de José García ${ }^{27}$, hijo de Cristóbal García maestro organero de la Santa Iglesia Catedral y de todo el obispado desde 1719 hasta el último tercio del siglo ${ }^{28}$. Al parecer la calidad artística de este órgano no debió ser muy grande ya que, al postularse el tándem García-Robles para la ejecución de los órganos que necesitaba la catedral, recién terminada la obra nueva, y ante la propia insistencia del obispo ${ }^{29}$ para que fueran estos artistas locales los que realizaran el proyecto, el cabildo manifiesta "la desconfianza con que quedaba el cabildo de que pudieran estos hacer el órgano con la perfección que se apetece, por hallarse noticioso de que el que fabricaron en la parroquia de los Santos Mártires de esta ciudad no tiene la suavidad que se requiere en las voces y, al mismo tiempo, que las obras que el citado Robles ha hecho en esta iglesia en los altares de San

22 A.C.C.M., 8 de junio de 1713 , tomo 40 , fol. 225 vto.

23 A.C.C.M. 13 de junio de 1713 , tomo 40 fol 230 vto.

24 A.C.C.M. 22 de diciembre de 1713, tomo 40, fol. 381

25 Vid. PEÑA GONZÁLEZ, J. J., Notas para una historia de a parroquia de los Santos Mártires Cyriaco y Paula V. de la Ciudad de Málaga, en Cirineo, $n^{\circ} 87$, año XXVI, diciembre 2000, págs. 17-18. En este artículo se puede observar una interesante fotografía procedente del Archivo Temboury donde puede apreciarse el órgano García-Robles situado en el coro alto de la iglesia.

26 Escultor malagueño. Había realizado para la catedral algunas obras como el retablo de San Luis en la Capilla del Rosario, el retablo dorado y jaspeado con la frontalera de San Francisco y otras tres frontaleras en la capilla del Rosario. Vid. LLORDÉN, op. cit. p. 19 (185).

27 JAMBOU, L., Evolución del órgano español, siglos XVI-XVIII, Documentos, Ethos Música, Servicio de Publicaciones, Universidad de Oviedo, 1988. Volumen $2^{\circ}$, p. 212. Cfr. RAMíREZ PALACIOS, A., Dinastías de organeros en Andalucía en los siglos XVIII y XIX. El Órgano español. Actas del II Congreso español de Órgano. Ministerio de Cultura. Madrid, 1987, p. 151-152.

28 Vid. PINO, A., DEL, Música en torno a Santa María de la Victoria, patrona de Málaga y su diócesis, en CAMACHO, R. (dir.), SPECULUM SINE MACULA, Santa María de la Victoria, espejo histórico de la ciudad de Málaga, (en imprenta), p. 368.

29 Según nos informa Juan Peña, en el Altar Mayor de los Mártires se encontraba una lápida, hoy desaparecida, donde se decía que el obispo Luís de Franquis Lasso de Castilla contribuyó a la obra de la Capilla Mayor y del órgano. 
Francisco y San Blas, no han sido de la mayor satisfacción"30. Además de la, según los capitulares, escasa calidad del instrumento, de lo costoso de sus mantenimiento y el cambio en los gustos estéticos durante el s. XIX, el instrumento de García caería en desuso a favor del práctico armonium que se impondría durante esta centuria en la práctica totalidad de las iglesias malagueñas, como podemos comprobar con el ejemplo de un organista de la Catedral que el día 1 de noviembre de 1862 encontramos en "La vigilia y misa que en el día de los Fieles Difuntos se ha de cantar en la parroquia de los Santos Mártires a las diez de la mañana, es compuesta por el profesor Juan Cansino y será oficiada por el armonium tocado por dicho señor"31.

Con respecto a los organistas que durante el s. XVIII ocuparon la tribuna de la parroquial de los Mártires, tenemos noticia de que en julio de 1713 "leyóse un memorial de D. Diego de Alcántara, Clérigo de Menores, en que pide se le nombre por organista de la Parroquial de los Santos Mártires de esta Ciudad, vacante por fallecimiento de D. Francisco Recio. Y en atención de ser discípulo de D. Miguel Conejos, y que se le ha oído tocar en el Organo de esta Iglesia con mucha destreza, se le nombró con el salario que tenía el difunto"32. Más tarde, en 1741, quedó vacante la dicha plaza por fallecimiento de Luis Palomares ${ }^{33}$, lo que mueve a Juan Carrillo a solicitarla:

"Señor Iltmo. Sr. Deán y Cavildo:

Juan Carrillo vezino de esta ciudad puesto a los pies de us ${ }^{a}$ con el debido vendimiento dice que haviendo muerto Luis Palomares, organista que era de la Parroquia de los Santos Mártires y aver servido en ella dos años las ausencias y enfermedades del dicho organista, y aver hecho dos oposiciones y en ambos exámenes merecido la aprobación y ser pobre de solemnidad, ciego y desvalido por tanto suplica a bizma que en dicha vacante entre con el ministerio de organista en propiedad a favor que espera merecer en el alto patrocinio de us ${ }^{a}$ Ultrma. a quien Dios conserve felisimos años en la mayor exaltación vuestra"34. El veredicto de Juan Francés de Iribarren, maestro de capilla de la Catedral es como se sigue en el informe dirigido al Deán:

"Cumpliendo con el precepto de V. S. Iltma.. en examinar a los opositores al órgano de los Stos. Mártires de esta ciudad (al que se han opuesto seis). He hallado a D. Juan Gómez, organista de Estepona, no vale nada absolutamente. D. Joseph Sánchez, vecino de Coín, toca más por afición, que por estudio algunas partituras de llano, sin methodo ni arte, sino de fanfarria propia; y esto es poco apreciable para la ninguna variedad, falta de manejo y suficiencia para lo preciso. D. Joseph Luque y D. Fco. Venavides (vecinos de esta ciudad) están tiernos y necesitan más de un año para perfeccionarse en lo preciso para una parroquia. Los que en realidad he

30 A.C.C.M., 15 julio 1776, tomo 52, fol. 370 vto. Cfr. LLORDÉN, op. cit. p. 19 (185).

31 El Avisador Malagueño, 1 de noviembre 1862.

32 A.C.C.M., 3 de julio de 1713 , tomo 40 , fol. 246

33 PEÑA GONZÁLEZ, op. cit. p. 17

34 (A)rchivo (C)atedral de (M)álaga (en adelante A. C. M.), leg. 304 pza. 1 y 2. 
hallado suficientes y que igualmente están aptos para ejercer dicho ministerio son D. Juan Carrillo orgta de San Felipe Neri y D. Cristóbal de Zafra, vecinos de esta ciudad. Esto lo digo desnudamente como lo siento en mi conciencia por lo que VS Iltma. Podrá hacer elección, en el que sea más de su agrado que es quanto ocurre decir a Vs Iltrima sobre este asumpto. D. Juan Francés de Iribarren"35. Como perito en la materia, además del maestro de capilla, informa el por entonces organista de la catedral, Nicolás González:

"Certifico D. Nicolás González Racionero orgta. de la Sta. Igl. Catedral de Málaga como Juan Carrillo hizo proposición del orgno de la parroquia de los Stos. Mártires de la ciudad de Málaga y aviendolo examinado en todo lo que es coincide para ser organista, de cualesquiera parroquia lo alle proporcionado y suficiente $y$ cumplio muy bien en composición y verdad lo firmo en Malaga en 14 de Marzo de 1741. D. Nicolás González Racionero. Orgta. de Málaga"36.

Resulta curioso comprobar cómo a pesar del veredicto favorable tanto del maestro como del organista de la catedral, la colación de dicho oficio no se efectúa hasta tres años más tarde: "En este Cabildo se nombró a D. Juan Carrillo Organista de la Parroquia de los Stos. Mártires de esta Ciudad, mediante informar de su aptitud el Sr. Maestro de Capilla que ha examinado a todos los opositores. Y se le mandó despachar Título en forma ${ }^{37}$ ". Tenemos noticia de que en 1755 , el citado organista seguía en su puesto: " $D$. Juan Carrillo, Organista en la Iglesia Parroquial de los Mártires de esta Ciudad, que pide su situado de renta en Fábrica; a Su llustrísima pasado se mandó acudir al Sr. Superintendente que informará al Cabildo para su pago"38.

De trascendental importancia podríamos calificar los singulares acontecimientos que tuvieron lugar a finales de siglo. Me refiero a los fastos relacionados con la inauguración de la nueva templo parroquial de los Santos Mártires en junio de 1777 y que fueron recogidos en verso por Juan Arias del Castillo en el Papel lírico que describe la plausible función, que se ha hecho en esta ciudad de Málaga, a la colocación del santísimo Sacramento en el altar mayor de la parroquia de los Santos Mártires Cyriaco y Paula, sus patronos ${ }^{39}$. En la introducción a esta obra, se da cuenta de la 35 Id.

36 Id.

37 A.C.C.M. 17 de diciembre de 1744 , tomo 46, fol. 251 vto.

38 A.C.C.M., 9 de Octubre de 1755, tomo 47, fol. 355 vto. Por tanto, la nómina de organistas de los Mártires, hasta donde sabemos, es la siguiente:

- $\quad$ Francisco Recio: muerto en 1713.

- $\quad$ Diego Alcántara: discípulo de Miguel Conejos. A partir de 1713.

- $\quad$ Luis Palomares: muerto en 1741.

- Juan Carrillo: procedía de San Felipe Neri. Sustituto del organista de los Mártires desde 1739. Oposita a la misma en 1741. Titular desde 1744. Continuaba en 1755.

39 Existe una edición facsímil preparada por Rosario Camacho y publicada por Unicaja y la Academia de Bellas Artes de San Telmo, Málaga, en 1995. 
participación de la Capilla de Música catedralicia tanto en la función del día $18^{40}$, como en la procesión del día $17^{41}$, que se abría con una tarasca, gigantes y enanos, además de los danzantes y el séquito. El marqués del Vado llevaba el estandarte de la ciudad seguido por las cofradías del Sagrario y los Mártires, aquélla con la imagen de San Pedro y ésta con la de los Santos Patronos. Iban después las representaciones de los conventos, el clero de las cuatro parroquias y la capilla de música de la Catedral, que antecedía al Santísimo Sacramento en su custodia de plata dorada. Al llegar al templo colocaron al Santísimo en el Sagrario y a los Mártires en su camarín, cantándose las Vísperas por la tarde ${ }^{42}$

La descripción de la música en la Plaza es la siguiente:

La música, con acentos

En quatro coros, se oía

Concertada melodía

Que suspendía los vientos:

Entre júbilo, y contentos

Lo acorde nunca cesava,

Y todo el que lo escuchava

Aseguró en conclusión

Que para aquella función

La Gloria en la Plaza estava ${ }^{43}$.

Al describir la procesión del día 17, nos cuenta que entre la tarasca y los gigantes y el estandarte de la ciudad iban:

Músicos con instrumentos

Y unas Danzas bien vestidos

Ivan; pero tan lucidos

Que baylaban de contentos.

Más adelante, en el lugar que hemos señalado:

De la Iglesia Catedral

Toda la música fue,

Tan bien concertada, que

Con ninguno tuvo igual .

Finalmente, cerrando la procesión:

\footnotetext{
40 Op. cit. p. 25.

41 Ibíd.. p. 29

42 Ibíd.

43 Id. p. 19.
} 
La Música que coloca

Este colmo a los intentos,

Tocó allí los instrumentos,

En todo, a pedir de boca.

En cuanto al novenario que se empezó a celebrar al día siguiente, festividad de los Patronos, se afirma en relación con la música:

\author{
Las armoniosas vozes \\ De tantos instrumentos \\ La oficiaron, y Músicos \\ Excedieron a las Aves en gorjeos \\ El estruendo cadente \\ O cadente el estruendo \\ Dio culto consonancias \\ Al Misterio que estava manifiesto. \\ (...) \\ Alternativamente \\ En todo aqueste tiempo \\ Tres coros de Música, \\ No cesaron de tocar fuera, y dentro \\ $Y$ asi en trinadas trompas, \\ Y obueés alagueños, \\ Con traveseras flautas \\ Poblaron los Timbales la región del viento. \\ En la Iglesia en su hora \\ Bolvieron los conciertos, \\ Porque en aquella tarde \\ El principio lo dio los intermedios. \\ Bien cantaron los músicos, \\ $Y$ tanto fue su esmero, \\ Que no se distinguía \\ Si la voz tocaba, o cantava el instrumento ${ }^{44}$.
}

El culto a los Patronos, como santos protectores de la ciudad, está muy vinculado a las rogativas que se realizaron para implorar el auxilio divino a través de su intercesión, debido a las diversas calamidades que azotaron a la población malagueña a principios del s. XIX ${ }^{45}$ :

44 La Capilla de Música de la Catedral vivía un momento de esplendor en 1777: bajo el magisterio de Jaime Torrens había por entonces alrededor de ¡40! Músicos entre organistas (2), sochantre y ayuda, salmistas (11), músicos de voz (10), seises (5) e instrumentistas (12).

45 CARRILLO, J. L., GARCÍA-BALLESTER, L., Enfermedad y Sociedad en la Málaga de los siglos XVIII y 
"En virtud de este acuerdo procedió el referido Comisionado a disponer la función en la forma siguiente: El martes 20 a las doce del día se anunciará la función de acción de gracias con repique general de campanas; a las dos y media de la tarde vendrá el Cabildo a la Catedral. Saldrá la Procesión por la puerta de las Cadenas e irán las Comunidades, Religiosos, el Clero, los Cabildos con los Stos. Mártires Patronos cantando hasta la Victoria el Himno "Sanctorum meritis"46. Desde la Victoria a la Plaza los Himnos a la Virgen y en recibiendo al Santo Cristo el "Te Deum laudamus". No habiendo bastantes Colegiales para llevar los Santos, se buscarán Clérigos que lo lleven. Se suponen tomadas de antemano por el Gobernador las providencias de policía para limpieza de la calle y adorno de los balcones para recibir con mayor solemnidad a la Santas Imágenes. Estará iluminada la Iglesia Catedral con todas las luces que debieran hacerse, empleadas la víspera de la Concepción. Al llegar a la Iglesia habrá toda la posible solemnidad de Música Marcial en la Calle y Eclesiástica en la Iglesia. Colocadas las Imágenes en sus sitios, cantará la Capilla un Motete, con lo que concluirá este día. A la noche iluminación general, que se repetirá los dos siguientes. El Miércoles primer día de la Octava después de la misa Conventual y Horas, habrá Misa Solemne con Su Majestad manifiesto, y Te Deum con Música y salvas. A la tarde después de Vísperas, Motete en el Presbiterio. En los 6 días siguientes, sólo habrá la Misa Conventual pero con Manifiesto y Te Deum solemne. El día $8^{\circ}$ por la mañana lo mismo que el primero, pero a la tarde habrá Procesión General con asistencia de todo el Clero, Comunidades Religiosas, inclusas las exentas Cofradías, Gremios, cantando estos el Santo Rosario y las Comunidades cada una en su Coro los Salmos 137: "Confitemini Domino"; 99: "Jubilate Deo" y 148: "Laudate Dominum de coelis" y Te Deum. Luego que la Virgen llegue a su Iglesia cantará la Capilla el Motete de esta tarde, y continuará la Procesión llevando al Santísimo Cristo a su Iglesia, donde se cantará otro Motete; y desde allí con los Santos Mártires a la Catedral ${ }^{47}$. El 17 de diciembre de 1803 , jornada en que se celebra el cabildo del que se extrae la anterior cita, es el día en que el Dr. Juan Manuel de Aréjula, facultativo enviado por la Junta Suprema de Sanidad, declaró oficialmente la terminación de la epidemia ${ }^{48}$.

No nos resistimos, a pesar de lo prolijo del texto, a reseñar íntegramente la siguiente anotación capitular, no sólo porque aparezcan referidos los Stos. Mártires, sino porque nos da una idea de la grandiosidad y magnificencia de las celebraciones decimonónicas malagueñas, además de ofrecernos una surtida relación de calles y plazas, algunas de ellas desaparecidas, por donde transcurrían las procesiones: "Hoy 29 a las 12 se anunció al Pueblo la Función con tres Solemnes repiques de campana en esta Sta. Iglesia, acompañando las Parroquias y conventos. A las dos y media se

XIX. La fiebre amarilla (1741-1821), Universidad de Málaga, 1980, p. 42 ss.

46 La única pieza musical con este título encontrada en el archivo es un himno gregoriano mensurado, que está en el cantoral $n^{\circ} 75$, fol. 25 , que es un antifonario para el común de santos. Dicho himno es para las primeras vísperas del común de varios mártires.

47 A.C.C.M., 17 de diciembre de 1803 , tomo 59, fols. 438 vto. -439 vto.

48 CARRILLO, op. cit., p. 44. 
entró en el Coro; se rezaron Vísperas, el Himno y Magnificat fueron cantados; enseguida Completas rezadas. A las 3 empezó a salir la Procesión, a la que concurrieron todos los Gremios, Hermandades, Cofradías, Órdenes Terceras, las Sagradas Religiones, inclusas las del Carmen, Trinidad Calzada, y los Ángeles, las 4 Parroquias con todo el Clero, y en medio de éste la Audiencia Eclesiástica seguía a la Cruz Catedral, y el Cabildo compuesto de los individuos que había, en el que eran los Sres. Magistral que iba de Preste, Bastardo de Diácono y Swerts de Subdiácono, Muñoz, Flores, Mújica y Torres; los Sres. Lachambre y Soto se excusaron por hallarse indispuestos, y Rambo estaba en patitur. Iban en medio del Cabildo las Imágenes de nuestros Santos Patronos, que por falta de Colegiales los llevaban cuatro Sacerdotes que se convidaron; detrás del Cabildo iba la Ciudad presidida del Sr. Alcalde Mayor que hace de Regente-Corregidor, y cerraba la procesión una Compañía de Granaderos con una Orquesta. El Cabildo llevó velas encendidas, y lo mismo la Ciudad. Como no ha habido en todo el tiempo de la epidemia ningún Colegial para el servicio de la Iglesia, mandó el Cabildo que los Acólitos se vistiesen de roquetes para el servicio de Altar, y lo han desempeñado con el mejor orden y acierto. Pero considerando que estos Ministros por ser tan jóvenes no podían sufrir el penoso trabajo de llevar la Cruz y los Ciriales por una Estación tan dilatada, se convidaron Clérigos de Menores para que supliesen la falta de los Colegiales, los cuales fueron con Dalmáticas, según lo hacen éstos en las Funciones de esta Sta. Iglesia. La Procesión salió por la Puerta de las Cadenas, Calle de San Agustín, la de Granada, Plazuela de la Merced, Arco de Santa Ana, Calle y Compás de la Victoria, y entrando en la Iglesia por la puerta colateral. En esta Estación se fue cantando el Himno de los Santos Patronos, y concluido se entonó el Salmo 135, el más a propósito para publicar la misericordia de Dios, acompañando a Fabordón los Bajones y Chirimías. Al llegar a la Iglesia fumigó el Preste a la Señora con dos ductos y se incorporó en la Procesión. Y se bajó por la misma Estación, sólo que se vino por toda la Calle Granada a la Plaza, dando vuelta por el lado de la Cárcel y las Casas Capitulares. Y al llegar a la embocada de la Calle Especerías, se incorporó el devoto simulacro del Santo Cristo de la Salud, el que llevaban 6 Sacerdotes con sobrepellices y estolas moradas, se concluyó la vuelta a la Plaza y subir por Calle de Santa María, a la entrar en esta Sta. Iglesia por la Puerta de las Cadenas. En esta Estación se fue cantando desde la Victoria hasta la Plaza los Himnos de Nuestra Señora, el Magnificat y el Salmo 135, alternando todos. Al incorporarse el Sr. de la Salud, se vino cantando el Te Deum. La Iglesia estaba iluminada como en la Nochebuena. Las Sagradas Imágenes se colocaron en la Capilla Mayor en el pavimento bajo el Stmo. Cristo al lado del Evangelio, y la Señora de las Victorias al de la Epístola. La Música cantó una Antífona de Nuestra Señora y el Preste dijo la oración de tempore: Gratiam tuam quaesumus; hubo una pequeña intermedia, y se cantaron los Maitines, el Himno y Benedictus fueron cantados con Órgano. La Iglesia permaneció iluminada hasta concluirse los Maitines. No se debe omitir la singular protección de Nuestra Señora ha usado con este su pueblo, pues hallándose los campos en necesidad de agua, al llevar la Imagen al Arco de la calle de 
Granada empezó a llover, y estuvo la Señora detenida el tiempo de 22 minutos que duró el agua; el tiempo se serenó todo el espacio que duró la Procesión hasta llegar a esta Sta. Iglesia, y al entrar en ella llovió lo muy suficiente con agua temporal y benéfica para el socorro de los campos y la salud. Día 30 se entró en el Coro a las 9, se rezó Prima y Tercia, Procesión y Misa Conventual del Apóstol San Andrés, que la cantó el Sr. Magistral; enseguida Sexta y Nona. Hubo una pequeña intermedia, habiéndose juntado todas las personas visibles del pueblo en un innumerable concurso, se empezó la Misa a las 10 y 10 minutos; ésta la cantó el Sr. Canónigo Lachambre, y fue votiva del Santísimo con Gloria y Credo; al Manifestar al Señor se dio un solemne repique y lo mismo al alzar la Sagrada Hostia. Y al concluir la Misa y entonar Te Deum, que se cantó de Canto Llano con la gravedad que pedian las circunstancia, acompañando las Chirimías por no haber Músicos de voz ni instrumentistas. Para la mejor decencia en el Altar Mayor se pusieron las gradas de plata, y encima se colocó la Capilla de plata para la Exposición del Augusto Sacramento, iluminando todo el Tabernáculo alrededor. El Sr. Magistral que duró 37 minutos, tomando por texto del Capítulo 12 de Isaías, del que formó una Homilía que excitó la devoción y reconocimientos que debemos a Dios en esta y todas ocasiones. Asistió la Ciudad, y habiéndole dicho el Sr. Magistral como Presidente y en uso de la facultades que tenía el Cabildo al Teniente de Rey que convidase a todos los Cuerpos Militares de la Guarnición de la Plaza y demás personas condecoradas, se pusieron para el efecto bancos en el ámbito de la lglesia, reservando 4 bancos de terciopelo debajo del púlpito del Evangelio para los Sres. que componían la Junta de Sanidad, la que convidó a dicho lugar al Sr. Provisor interino. Y con motivo del concurso tan numeroso que había, fue necesario que ésta entrase formada desde la Sacristía por la Capilla Mayor, y saliese por medio de la valla a ocupar su lugar. La función se concluyó a las 12 y un cuarto, admirando todos los concurrentes el decoro y magnificencia con que se han celebrado los Divinos Oficios con pocos individuos. La Junta de sanidad continuando sus esmeros en el obsequio del público de esta Sta. Iglesia, pasó formada a las casas del Sr. Magistral a darle personalmente la en hora buena y las gracias por haber desempeñado tan a satisfacción de todos el Sermón. Suplicándole le entregase el borrador de él para publicarlo impreso, y el público no careciese de tan precioso testimonio de su reconocimiento; y el Sr. Magistral excusándose a ello, venció en su moderación las súplicas de la Junta y lo entregó. $A$ la tarde se entró en Vísperas a las 2 y media, se rezaron como todo el tiempo de la epidemia, a excepción el Himno y el Cántico del Magnificat que fueron con Órgano, por no haber suficientes Ministros, siguieron Completas, Maitines y Laudes, todos rezados menos el Himno de Laudes y el Benedictus que fueron a Órgano y con capa. En seguida se salió del Coro de Menor con luces encendidas como en la Octava del Corpus, y en medio de la Capilla Mayor se cantó por los Salmistas y Bajones el Alma Redemptoris Mater a Canto Llano, y mientras se turificaron las Sagradas Imágenes por su orden, y concluida se dijo por el Preste la oración de tempore. El Cabildo mandó que por razón de las circunstancias y el concurso del pueblo se entrase todas las mañanas de la Octava a las 9, y en las tardes se hiciese lo mismo que hoy; pero 
que la Iglesia se quedase abierta por las mañanas hasta las 12, y por las tardes hasta la oración para satisfacer la devoción del pueblo que viene a adorar a Dios y a su Santísima Madre. Día 1 de diciembre, sábado, los Oficios Divinos Oficios se celebraron como ayer: Misa con Santísimo patente y Te Deum; a la tarde lo mismo. Día 2, Domingo primero de Adviento, se ejecutó lo mismo que ayer, con la diferencia que hubo Sermón por la Dominica. Día 3, lunes, se celebraron los Divinos Oficios en la forma dicha. Es de notar que en estos días no ha concurrido la Ciudad"49. Al igual que en el caso anterior, todos estos fastos tienen que ver con el nuevo brote de fiebre amarilla que azotó a la población malagueña a partir de agosto de 1804 hasta finales de año ${ }^{50}$.

Las dos siguientes referencias que encontramos en las Actas Capitulares conciernen al pago de músicos convidados para la festividad de los Stos. Mártires, asunto que es fácilmente comprensible y absolutamente necesario si tenemos en cuenta que las anteriores epidemias habían literalmente esquilmado la capilla de música de la Catedral dejándola nada menos que con catorce miembros menos, incluido el maestro de capilla, Jaime Torrens ${ }^{51}$.

También encontramos vínculos del culto a los Santos Patronos con acontecimientos relacionados con la realeza: "Se volvió a leer la Real Orden de Su Majestad el Sr. D. Fernando VII, fecha 7 de este mes, a fin de que se hagan Rogativas por feliz acierto con el gobierno de sus Reinos; y teniendo presente los Acuerdos Capitulares de 14 de febrero de 1724, de 25 y 26 de agosto de 1746, de 7 y 8 de enero de 1789, se determinó que el lunes 18, segundo día de Pascua de Resurrección, después de la Misa Solemne se cante el Te Deum en acción de gracias por la exaltación al trono del Sr. D. Fernando VII, al modo que se hizo en 1724 por el Sr. D. Luís I cuando renunció el Sr. D. Felipe V, su padre; que por la tarde a las 4 se celebre Procesión general con asistencia del Ayuntamiento, todo el Clero secular y regular, Cofradías y Gremios con los Sres. Patronos San Ciriaco y Santa Paula al Convento de Ntra. Señora de las Victorias, Patrona de esta Ciudad, de rogativa por el acierto de nuestro actual Soberano en el gobierno de estos Reinos; la cual se dirija por la Calle de San Agustín, Puerta de Granada, Arco de Santa Ana y Calle de la Victoria, y que vuelva a esta Sta. Iglesia por los mismos sitios; y al día siguiente 19, último de dicha Pascua, Misa Solemne de Rogativa con igual fin, después de Nona; y concluidas las preces acostumbradas conviniéndose Su Iltma. a quien lo comunique el Sr. Málaga, Presidente, que por el Sr. Provisor se avise a las Parroquias y Conventos, y se convide a la Ciudad por medio del Maestro de Ceremonias según estilo; y se nombraron de

49 A.C.C.M., 29 de noviembre de 1804, tomo 59, fols. 565-568 vto. Esta amplia cita nos permite comprobar entre otros sabrosos detalles, el uso todavía vigente a principios del s. XIX de instrumentos tan arcaicos como las chirimías. También los bajones incluso 30 años más tarde como veremos en la misa que se encarga a Reig, aunque muchas veces el nombre de bajón se usa a veces de forma indistinta con el de fagot desde finales del s. XVIII independientemente del estadio en la evolución del propio instrumento.

50 CARRILLO, op. cit. pp. 44-45.

51 MARTÍN TENLLADO, G., Eduardo Ocón. El nacionalismo musical. Seyer. Málaga. 1991. p. 264 y 288. A.C.C.M., 25 de junio de 1805, tomo 60, fol. 85 vto. y 3 de julio de 1807, tomo 60, fol. 407. 
Comisionados para dicha función a los Sres. Canónigos Magistral y Calvo para que la dirijan con los que elija la Ciudad, previniéndoles que manifiesten al Sr. Gobernador le agradecerá el Cabildo que al tiempo de repique general al cantarse el Te Deum en la Catedral y Parroquias, correspondan las salvas de artillería de la Plaza; y cuarto, que se participe a Su Majestad por su Secretario de la Real Cámara y Patronato de Castilla todo lo que se ha practicado en cumplimiento de la referida Orden"52.

Durante la era napoleónica, 1808-1814, el culto a los Patronos se mantuvo sustancialmente como se recoge en el Quaderno de Obligaciones ${ }^{53}$ y todo ello a pesar de la sustancial merma en las filas musicales catedralicias: desde 1807 hasta 1816 no se producen incorporaciones, sino que, por el contrario, hay que contabilizar cinco bajas ${ }^{54}$.

Encontramos otra anotación en las Actas Capitulares que relaciona el culto a los Patronos con las rogativas por la casa real, en este caso por la salud del mismo monarca Fernando VII, en 1832: "Enseguida se vio también un Oficio del Iltmo. Sr. Obispo, fecha de este día, insertándole la misma Real Orden, invitando al Cabildo para que sin tardanza alguna se empezasen en esta Sta. Iglesia las Rogativas por la preciosa salud del Rey, nuestro Señor. Y en su consecuencia muy condolido el Cabildo con tan triste noticia, y muy deseoso de cumplir las piadosas intenciones del Gobierno y de Su Iltma., acordó conforme a las insinuaciones de éste, que en esta misma tarde se pongan en el Altar Mayor las Sagradas Imágenes de Nuestra Señora de los Reyes y Señor San Rafael; que se haga Procesión general a la Iglesia de Nuestra Señora de la Victoria, desde la cual se conduzca su Sagrada Imagen a esta nuestra Sta. Iglesia Catedral, viniendo la procesión a la del Stmo. Cristo de la Salud para traer también la Imagen y la de los Santos Patronos, cantándose las Letanías y demás Preces acostumbradas; a cuyo fin se darán las ordenes convenientes para que concurran las Parroquias, Comunidades, Cofradías y demás que deban concurrir en caso de tanta importancia como éste; que mañana después de Nona se cante una Misa solemne Pro infirmis, con el Stmo. Sacramento manifiesto, y las Preces correspondientes, continuándose éstas en los siguientes días después de la Misa Conventual con el Sagrario abierto por el tiempo que dure la necesidad. Todo lo que se pondrá en conocimiento de Su Iltma., nombrando para este fin por los Comisionados a los Sres. Tesorero y Tenorio, y adelantándose el Coro de esta tarde media hora de lo acostumbrado; y se darán las demás disposiciones necesarias para que todo tenga el más puntual cumplimiento"55.

52 A.C.C.M., 16 de abril de 1808 , tomo 61 , fols. 38 vto.-39 vto.

53 TORRE MOLINA, M ${ }^{\mathrm{a}} \mathrm{J}$. DE LA, La música en Málaga durante la era napoleónica (1808-1814), Servicio de Publicaciones, Universidad de Málaga, 2003, p. 167. Vid. Apéndice $2^{\circ}$, p. 322

54 Libro de las Fiestas de la Capilla de Música, (A)rchivo de (M)úsica de la (C)atedral de (M)álaga (en adelante, A.M.C.M.), 265-1, fols. 72 ss. Citado en MARTíN TENLLADO, op. cit., p. 293.

55 A.C.C.M., 22 de septiembre de 1832, tomo 64, fols. 115 vto.-116. 
Como sabemos, los procesos desamortizadores iniciados en el segundo tercio del siglo XIX dieron al traste para siempre con los intentos de reorganización que la Catedral había intentado para con su capilla de música desde el fin de las epidemias de 1803 y $1804^{56}$, pero el cabildo, celoso siempre en la salvaguarda de la solemnidad en la celebración de los Santos Patronos, acordó una serie de medidas para mantener la mayor dignidad musical posible al menos en determinadas fiestas al año, entre las que se encuentra la de San Ciriaco y Santa Paula, a pesar del esfuerzo económico que, a partir de entonces, tendría que realizar el Cabildo siempre que quisiera mantener, aunque fuera pálidamente, el esplendor de los cultos de antaño: "precedida citación en el día anterior a todos los Sres. Dignidades y Canónigos de esta Sta. Iglesia, por Cédula del Sr. Presidente de que dio fe el Pertiguero, para discutir el Plan de Reformas, se reunieron en la Sala Capitular después de Coro, los Sres. Deán, Málaga, Maestrescuela, Ronda, Vélez, Lectoral, Bolaños, García y Doctoral (...) se delibera lo siguiente: Puede haber Música con 2 Violines y Violonchelo en los 3 Días de Carnaval al Motete, como igualmente toda la Octava del Corpus al ocultar, y después de Maitines de Todos los Santos, por saber tocar dichos Instrumentos D. José Velasco, D. Andrés Salas y D. Juan Villarreal. Con los Salmistas de las Festividades de Circuncisión, Purificación, San José, la Misa del Jueves Santo y Sábado Santo, en el Laudate Dominum y Magnificat y Primer Día de Pascua de Resurrección, Ascensión, Pascua de Pentecostés, las primeras Vísperas del día primero y a Misa del $1^{\circ}$ y $2^{\circ}$ días en la Santísima Trinidad, el Domingo infraoctava del Corpus, a la Misa de San Fernando, los Santos Patronos, San Juan Bautista, la Virgen del Carmen, Santiago, Asunción y Natividad de Ntra. Señora, San Luís, Obispo, la Dedicación de esta Sta. Iglesia, Todos los Santos, Purificación de Ntra. Señora, el Día octavo de la Purísima, Primer Día de Navidad y San Juan Evangelista.

Todos los demás días de Facistolillo, según consta en el Cuaderno de obligaciones que arreglado en la Sacristía Mayor de esta Sta. Iglesia Catedral.

Se suprimen para siempre las Siestas de Música que ha habido todos los días en la Octava del Corpus, por lo cual se entrará a las cuatro después de un corto intervalo y las Completas, se entrará en Maitines; todo lo que hasta ahora ha sido cantado y los 3 Nocturnos de Maitines que se rezan, se hará grave en término que ocupe el tiempo hasta la hora de reservar el Santísimo Sacramento; a cuyo fin el Sr. Deán o Presidente prevendrá todos los años a los Músicos, Sochantre, Salmistas y Organista, para que coopere cada uno por su parte a que se verifique exactamente esta determinación del Cabildo.

Igualmente se acordó que antes que el Maestro de Capilla proceda a convidar a los Profesores de Música para los días de Orquesta, se ponga de acuerdo con el Sr. Deán o Presidente para ello, prefiera en esta convite a los que hayan servido en esta

56 MARTÍN TENLLADO, op. cit., p. 269 y 327 ss 
Sta. Iglesia, a los que advertirá que para la asistencia al Coro al que son convidados, han de presentarse con traje negro y decente, sin cuya cualidad no serán admitidos a la Orquesta en dichos días.

También se dirá al mismo Sr. Maestro de Capilla que para las Exequias y Entierros de los Sres. Prelados y Prebendados de esta Sta. Iglesia prepare y disponga un Oficio completo de Difuntos a papeles, sin más acompañamiento de Instrumentos que los de dotación, a saber: Bajones y Clarinetes ${ }^{57}$, cuyos Oficio servirá también en las Honras anuales a los Sres. Reyes Católicos" $" 58$.

Esta misma situación de penuria económica y de escasez de los recursos humanos, dará al traste con el boato con que se celebraba la solemnidad de los Patronos durante la segunda mitad del s. XVIII ${ }^{59}$. Baste comprobar de qué forma tan simple se suprime en 1835 una procesión que se ha podido documentar desde el siglo XVI60: "El Sr. Deán propuso que en atención a las circunstancias actuales en que se encuentra esta Sta. Iglesia de escasez de Ministros, y por estar licenciado el Colegio Seminario, falto el de Seises, enfermos, ausentes y vacantes un considerable número de Prebendados, e imposibilitado el paso por una de las Calles principales, le pareció se suspendiera por este año la Procesión a los Santos Mártires, por la Festividad de los Santos Patronos de esta Ciudad. Y el Cabildo teniendo en consideración los motivos referidos, y que la Función es trasladada y no en día propio, acordó aprobar la propuesta del Sr. Deán, conviniendo el Sr. Gobernador del Obispado que estaba presente, en que las causas eran suficientes para esta suspensión"61. Y también en 1837: "Se acordó que en el presente año fuese el Cabildo a la Iglesia de los Santos Mártires Patronos en el día de su Festividad a celebrar la Función a causa del corto número de individuos de que actualmente consta; lo cual se avisase a la Parroquia para su conocimiento; y que el día anterior a las doce hubiese repique solemnizándose la Función y Festividad Tercia cantada a Fabordón, Procesión de Capas por todo el ámbito de la Iglesia, y que la Misa de Tercia se verifique con Música de papeles, avisando este acuerdo a la Sacristía, Campanero, Maestro de Capilla y demás a quienes corresponda"62.

57 No hemos encontrado en todo el catálogo de Mariano Reig, maestro de capilla en este periodo, ninguna obra bajo el título "Oficio de difuntos". Sin embargo, hemos encontrado una Misa, fechada en mayo de 1835, en cuyo comienzo del Kyrie se puede observar fácilmente el cantus firmus del introito de las Misas exequiales: Réquiem Aeternam. La instrumentación de esta Misa se corresponde además con lo dispuesto en el acuerdo capitular de enero de ese mismo año. Vid. MARTín MORENO, A. (dir.), Catálogo del Archivo de Música de la Catedral de Málaga, Centro de Documentación Musical de Andalucía, Granada, 2003, p. 804. A.M.C.M, pieza 156-3.

58 A.C.C.M., 22 de enero de 1835, tomo 64 , fols. 311 vto.-312 vto

59 SARRIÁ MUÑOZ, A., Religiosidad y política. Celebraciones públicas en la Málaga del siglo XVIII, Málaga, 1996, p. 20 ss., también PALOMO CRUZ, A. J., Los Santos Patronos de Málaga, apuntes para su historia y devoción, en Via Crucis, $n^{\circ}$ 9, 1991, p. 17 ss.

60 Cfr. MESSA POULLET, C., La música en la Catedral de Málaga durante el Renacimiento, Tesis doctoral inédita, Granada, 1997,4 vols. Vol. $2^{\circ}$, p. 527 ss.

61 A.C.C.M., 1 de julio de 1835 , tomo 64 , fols. 348 vto.-349

62 A.C.C.M., 12 de junio de 1837, tomo 64 , fol. 520 
En último lugar, y como curiosidad, reseñamos el acuerdo capitular por el que se decide la nota que debe dar la nueva campana bautizada con el nombre de los Santos Patronos: "El propio Sr. García presentó el papel redactado Sr. Maestro de Capilla de los tonos que deberán tener las nuevas campanas que han de fundirse, en armonía y consonancia con las otras que existen en la torre. Y su dictamen es como sigue (...) Santos Patronos: Deberá ser su tono el de SOL"63. Quizás pueda parecernos un poco tardío el año 1851 como fecha para decidir el tono que debe dar una campana, sobre todo si tenemos en cuenta que la torre se concluyó en la década siguiente a $1770^{64}$ y que en $1784^{65}$ se encargan a Fernando Venero Vizcaíno ocho campanas que se realizaron en Málaga, aprovechándose algunas de las anteriores para completar el broncíneo conjunto ${ }^{66}$. Entre las ocho campanas nuevas se encuentra la de "Los Santos Patronos, San Ciriaco y Santa Paula", con el considerable peso de 176 arrobas $^{67}$, que servía para tocar con ella "a fuego, cinta ${ }^{68}$, rogativas, y al Sermón, y llamar a los Campaneros, y solo se echará a vuelo en la festividad del Corpus Christi" ${ }^{\prime \prime}$. Suponemos el funcionamiento normal de las campanas según el Libro de Addiciones hasta que en 1836 la Junta General de Gobierno requisa al Cabildo todas las campanas dejando sólo tres para las necesidades del culto ${ }^{70}$. El cabildo pide para que en lugar de tres sean cuatro las que dejen para poder dedicar la cuarta a la iglesia capitular del Sagrario, petición que es finalmente aceptada y se manda comunicar al gobernador del obispado para que "al presentarse los encargados del derribo de las expresadas campanas se lo puedan hacer asi constar para su cumplimiento"11. En la actualidad, con el nombre de los Santos Patronos encontramos una campana con la siguiente inscripción: "Me hizo D. Ramón y D. MANUEL Rivas. AÑo de 1887"72.

63 A.C.C.M., 1 de septiembre de 1851, tomo 66, fol. 463.

64 Cfr. LLORDÉN, A., Historia de la construcción de la Catedral de Málaga, Colegio Oficial de Aparejadores y Arquitectos Técnicos, Málaga, 1988, p. 271.

65 A.C.C.M. 20 de agosto de 1784, tomo 54, fol. 436 y 25 de noviembre de 1784, tomo 54, fol. 502.

66 Addiciones al Libro que esta Santa Iglesia Catedral de Málaga tiene para el gobierno de su Torre, y Campanas, y de las obligaciones del Campanero, 1786.

67 Unos 2024 kg. si estimamos la arroba en 11 kilos y medio aprox. Por otra parte, este peso casi coincide con el de la actual campana de Santiago fundida en 1908 no sabemos si con el metal de la antigua campana de los Patronos o simplemente para colocarse en el lugar que ocupaba ésta y, por tanto, de peso y dimensiones parecidas.

68 Podríamos relacionar este toque con el hecho prodigioso ocurrido en el pueblo Villar de Cañas de la provincia de Cuenca el día 14 de enero de 1635, cuando era llevada la santa cinta a Madrid para el embarazo de la Reina y, al pasar la Reliquia frente a la ermita de Nuestra Señora de la Cabeza que allí se venera, se puso a tocar la campana por sí sola largo rato. Por tanto, aventuramos que el toque "a cinta" pudiera estar destinado a anunciar los embarazos reales.

69 Ibíd.

70 A.C.C.M., 6 de septiembre de 1836, tomo 64, fol. 447 vto. Citado en MARTíN TENLLADO, op. cit. p. 329.

71 A.C.C.M., 7 de septiembre de 1836 , tomo 64 , fol. 448 vto.

72 Debemos toda la información sobre las campanas de nuestra Catedral, así como la reproducción del "Libro de Addiciones..." a la página www.campaners.com, donde se encuentran los inventarios de las Catedrales, Colegiatas e iglesias principales de España, así como las fichas realizadas en 1998 por Álvaro Mendiola. 
$2^{\circ}$ Relación de obras dedicadas a los Patronos que se hallan en el archivo de la Catedral, sección Música ${ }^{73}$.

REPERTORIO GREGORIANO.

a) Misas: En el cantoral $n^{\circ} 5$ para las Misas de Santos (s. XVII) y en el $n^{\circ} 14$ para las Misas propias de la Iglesia de Málaga (1704), encontramos las partes propias (introito, gradual, aleluya, ofertorio y comunión) para la festividad de San Ciriaco y Santa Paula. Dicho repertorio puede ser cotejado con sus equivalentes en el Liber Usualis y en el Graduale Triplex, si bien con notables diferencias en algunos casos, que pueden hacer dudar de la pureza de las fuentes consultadas por los copistas malagueños $^{74}$.

b) Oficio Divino: en el cantoral $n^{\circ} 75$ (s. XVIII), encontramos a partir del folio 22 v. las primeras y segundas vísperas para el común de mártires, que puede ser cotejado con lo contenido en el Liber Usualis para dicho oficio, así como la antífona Impii super iustos, fol. 64 v., de la que no se encuentra paralelo alguno en otros repertorios. En el cantoral $n^{\circ} 82$, no hay música, pero se encuentran los salmos que debían cantarse 0 recitarse en la festividad de los Patronos en el folio 49.

c) Procesiones: El cantoral $n^{\circ} 90$ (s. XVII) y los catalogados como Liturgia 75 (1729) y Toledo 69 (siglos XVII-XVIII) se complementan y contienen los Responsorios y Versículos que se deben cantar en las procesiones (entendemos que tanto las claustrales como las que se hacían con las imágenes de los Patronos o, incluso, hacia su iglesia). Curiosamente, el responsorio $3^{\circ}$, Tradiderunt, es al que pondría música Sanz, como veremos más adelante.

Música de PAPELES.

A.M.C.M. Pieza 174, 3.

Autor: Francisco Sanz, maestro de capilla entre 1684 y 1732.

Fecha: sin año.

Título: Motete a 4 con órgano.

Forma musical: Motete.

Género: Vocal-instrumental.

Tempo: sin indicación de tempo.

Tonalidad: modo $8^{\circ}$.

Plantilla: tiple, alto, tenor, vaxo y órgano.

Letra:

Tradiderunt corpora sua propter Deum ad suplicia et meruerunt habere coronas

73 Las presentamos ordenadas cronológicamente.

74 Para todo lo relacionado con el repertorio de canto llano en el Archivo de Música, vid. VEGA GARCíAFERRER, J., Los cantorales de canto llano de la Catedral de Málaga, Centro de Documentación Musical de Andalucía, 2007 
perpetuas. Isti sunt qui venerunt ex magna tribulatione et laverunt stolas suas in sanguine Agni ${ }^{75}$.

A.M.C.M. Pieza $62,6$.

Autor: Juan Francés de Iribarren, maestro de capilla entre 1733 y 1767.

Fecha: 1745.

Título: Motete a 4 con violines, trompa y baxon a los Stos. Patronos Ciriaco y Paula.

Forma musical: Motete.

Género: Vocal-instrumental.

Tempo: A medio ayre.

Tonalidad: Mi b mayor.

Plantilla: tiple $1^{\circ}$, tiple $2^{\circ}$, alto, tenor, violín $1^{\circ}$, violín $2^{\circ}$, trompa $1^{a}$, trompa $2^{a}$, baxon, acompañamiento ${ }^{76}$.

Letra:

Impii super iustos iacturam fecerunt, ut eos morti traderent, at illi gaudentes susceperunt lapides ut mererentur accipere coronam gloriae.

\section{A.M.C.M. Pieza 195, 8.}

Autor: Jaime Torrens, maestro de capilla entre 1770 y $1803^{77}$.

75 La segunda mitad del texto se corresponde con los versículos 14 y 15 del capítulo $7^{\circ}$ del Apocalipsis.

76 Desde que transcribimos y recuperamos para el culto este motete de Iribarren, advertimos en la parte de violín un tipo de escritura que nos hacía recordar el concepto vivaldiano de "violino in tromba", que podemos escuchar en los conciertos RV 221, RV 311 y RV 313. Además de la textura de la propia parte de violín en sí, hemos tenido en cuenta dos circunstancias a la hora de confirmar nuestra hipótesis: el hecho inusual de que Iribarren escriba una sola parte de violín, cuando lo habitual es que lo haga a dos violines (raramente tres violines o dos violines y viola), lo que parece indicar que quiere dar más fuerza a esta parte recurriendo al unísono y, por otro lado, sabemos que los instrumentistas de viento-metal (los que tocaban los clarines y las trompas) eran los mismos que usaban alternativamente ambos instrumentos. De hecho, en muchas composiciones observamos la parte de clarín $1^{\circ}$-trompa $1^{\mathrm{a}}$ en el mismo papel, al igual que el clarín $2^{\circ}$-trompa $2^{\mathrm{a}}$, que va cambiando de clave indicando con ello el cambio de instrumento (clave de sol para el clarín y de fa para la trompa). Como en este breve motete ya están "utilizadas" las dos trompas y no se prevé el uso alternativo con los clarines, entre otras cosas por tratarse de una sola y breve composición, la parte supuestamente dedicada a estos es pasada a los violines al unísono en la textura que, como decíamos, recuerda el uso que a veces hacía Vivaldi de los violines (y de otros instrumentos) en defecto de las trompetas. Cfr. TALBOT, M., "Vivaldi", Alianza Música, Madrid, 1990, págs. 35 y 140. Además, después de haber comprobado empíricamente en reiteradas ocasiones lo adecuado (y lucido) del uso de la trompeta pícolo para esta parte de violín podemos utilizar el adagio latino que sostiene que "Contra facta non valent argumenta". Dicha comprobación ha sido posible gracias a la colaboración del soberbio trompetista José Antonio Moreno, solista de la Banda Municipal de Música de Málaga.

77 Las letras de los villancicos estaban sometidas a la censura, lo que explica el hecho que, recién incorporado a la Capilla, Torrens preguntara por quién debía "reconocer la letra antes de mandarlas a la imprenta" (A.C.C.M., tomo 51, fol. 270). Sabemos que, en la época de Iribarren, el autor de la letra de muchos villancicos fue el poeta de la Corte José Guerra (Archivo Catedral de Málaga, leg. 616, carta de Alejandro Ferrer de 5 de agosto de 1749 solicitando el puesto de José Guerra; también LLORDÉN, A., Notas históricas de los Maestros de Capilla en la Catedral de Málaga (1641-1799), en Anuario Musical, $n^{\circ} 20,1965, p .148$ ) y más tarde Alejandro Ferrer (A. C. M., leg. 616, carta de Alejandro Ferrer de 2 de septiembre de 1749 agradeciendo su admisión; más ampliamente, ALVAR, M., Villancicos dieciochescos, Málaga, 1973). Durante el periodo en que se compuso la colección de villancicos de Torrens dedicados a los Patronos, el cabildo malacitano contó con Miguel Pérez Bailón, poeta malagueño y maestro mayor de las reales escuelas, quien se mantendría en este puesto hasta 1798, año en que fue suprimido este género en las catedrales españolas (A.C.C.M., tomo 52, fol. 151 vto., 11 de noviembre de 1775 y tomo 57, fol. 554, 14 de noviembre de 1798). Vid. MARTíN QUIÑONES, M. A., La 
Fecha: 1782.

Título: Villancico a 6 a los SS. Martyres con violines y trompas.

Forma musical: Villancico.

Género: Vocal-instrumental.

Tempo: Andante. Coplas despacio.

Tonalidad: Do mayor.

Plantilla: alto, tenor ( $1^{\circ}$ coro), tiple, alto, tenor, bajo $\left(2^{\circ}\right.$ coro $)$, violín $1^{\circ}$, violín $2^{\circ}$, trompa $1^{\mathrm{a}}$, trompa $2^{\mathrm{a}}$, acompañamiento.

Letra:

Hoy con devoción corriendo llegad, / si a vuestros Patronos queréis celebrar./ Sus gracias derraman en esta ciudad,/ venid a sus cultos, corriendo llegad./ Pedid confiados que os remediaran,/ el clamor levante la voz a compás./ Hoy con devoción llegad. Venid, llegad/ si a vuestros Patronos queréis celebrar.

A.M.C.M. Pieza 197, 10.

Autor: Jaime Torrens.

Fecha: 1782.

Título: Villancico a dúo a los Santos Mártires con violines.

Forma musical: Villancico.

Género: Vocal-instrumental.

Tempo: Recitado. Aria a dúo, largo. Allegro. Largo.

Tonalidad: Mi menor.

Plantilla: Tiple y alto a dúo, violín $1^{\circ}$, violín $2^{\circ}$, acompañamiento.

Letra:

Mártires santos, campeones fuertes, / llama de amor despiden vuestros pechos./ Impetradnos de Dios las buenas suertes/ de ser en tal volcán de amor desechos./ Tú Ciriaco feliz, tú Paula hermosa,/ fuiste en la eterna luz cual mariposa,/ os colmó del esfuerzo más valiente,/ os abrasó en la llama más ardiente,/ para que así en su tálamo sagrado/ os unáis al Cordero inmaculado./ Tú Paula preclara, tú invicto Ciriaco,/ dad esfuerzo al flaco,/ Tú libra, tú ampara la grey del Señor./ Los bienes alcanza del brazo divino,/ pues tu pueblo fino/ su dicha afianza en vuestro favor.

A.M.C.M. Pieza 200, 4.

Autor: Jaime Torrens.

Fecha: 1783.

Título: Villancico a solo a los SS. Mártires con violines.

Forma musical: Villancico.

Género: Vocal-instrumental.

Tempo: Recitado. Andante moderato. Aria, andante poco. Allegro.

Tonalidad: Sol menor.

música en la Catedral de Málaga durante la segunda mitad del siglo XVIII: Vida y obra de Jaime Torrens. Tesis doctoral inédita, 1997, 3 vols. Vol. 1º, p. 416. 
Plantilla: Tiple, violín $1^{\circ}$, violín $2^{\circ}$, acompañamiento.

Letra:

O adalid invencible en los combates/ feliz Ciriaco que al tirano abates/ protege tus devotos consolando/ a cuantos a tu amparo están clamando/ y tu Paula feliz que trasladada/ del tronco vil a celestial morada/ por el Iris de paz ya te venera/ este pueblo/ obsequioso que en ti espera/ y en tu favor confía/ ver de la luz el permanente día./ Dad mártir, dad con pasos diligentes/ el favor que te piden hoy las gentes./ Si mi esperanza, si mi consuelo/ solo en el cielo debo fijar/ no desconfío patrón glorioso/ que poderoso me has de amparar.

\section{A.M.C.M. Pieza 204, 2.}

Autor: Jaime Torrens.

Fecha: 1783.

Título: Villancico a 7 a los SS. Martyres con violines y clarines.

Forma musical: Vocal-instrumental.

Género: Villancico.

Tempo: Estribillo, allegro vivo. Coplas, largo.

Tonalidad: Re mayor.

Plantilla: Tiple $1^{\circ}$, tiple $2^{\circ}$, alto $1^{\circ}$, alto $2^{\circ}$, tenor $1^{\circ}$, tenor $2^{\circ}$, bajo, violín $1^{\circ}$, violín $2^{\circ}$, clarín $1^{\circ}$, clarín $2^{\circ}$, acompañamiento.

Letra:

Religioso jardín, excelente ciudad/ que a Paula y Ciriaco obsequios le das. I

Aplaudid, celebrad, tributando el honor y alabanza a quien quiso tu tierra ilustrar. / Aplaudid celebrad, que aunque más tributéis rendimientos no podréis su favores pagar. / Aplaudid, celebrad, pues clamores humildes y ruegos pueden mucho del cielo alcanzar / En el amparo confía de Ciriaco y su bondad / que en la presencia divina te alcance felicidad.

\section{A.M.C.M. Pieza 188, 12.}

Autor: Jaime Torrens.

Fecha: 1783.

Título: Villancico a solo a los SS. Martyres Ciriaco y Paula con violines y trompas.

Forma musical: Villancico.

Género: Vocal-instrumental.

Tempo: Recitado. Aria largo, allegro, largo, allegro.

Tonalidad: Mi b mayor.

Plantilla: Tenor solista, violín $1^{0}$, violín $2^{\circ}$, trompa $1^{a}$, trompa $2^{a}$ y acompañamiento.

Letra:

Complácete bella ciudad, habitación hermosa,/ gózate de tus grandes esplendores/ llenándote de glorias y de honores,/ pues ya Ciriaco y Paula tus Patronos/ 
mostrarán de tus dichas los abonos,/ tributa cultos, con fervor porfía,/ aliento toma y en los dos confía./ Oh! bella población, feliz terreno!/ canta tu suerte de alegría lleno/ porque propicio Dios te ha enriquecido/ y con tal excelencia ennoblecido./ Mansión dichosa, terreno santo/ con dulce canto la voz alzad:/ que el gran Ciriaco y Paula hermosa/ de ver se goza vuestra piedad.

A.M.C.M. Pieza 189, 7.

Autor: Jaime Torrens.

Fecha: 1783.

Título: Villancico a 7 a los SS. Martyres Ciriaco y Paula con violines.

Forma musical: Villancico.

Género: Vocal-instrumental.

Tempo: Estrivillo andante. Dos coplas al mismo ayre.

Tonalidad: Sol menor.

Plantilla: Tiple, alto, tenor ( $1^{\circ}$ coro $)$ tiple, alto, tenor, bajo $\left(2^{\circ}\right.$ coro $)$, violín $1^{\circ}$, violín $2^{\circ}$ y acompañamiento.

Letra:

Christiano pueblo fiel llegad con devoción, / llegad a dar rendidos cultos en Aras del Señor. / A Paula y a Ciriaco celebra/ pues se vio tu tierra matizada con sangre de los dos/ para que vuestros ruegos merezcan su atención/ de quien rendir no pudo la astucia infiel a Dios/ Paula, bella es tu alegría, es tu amparo y protección/ que ruega con eficacia por vuestro total favor/ Al gran Ciriaco invencible tributad vuestro loor/ porque del trono divino impetra la protección.

\section{A.M.C.M. Pieza 207, 2.}

Autor: Jaime Torrens.

Fecha: 1785.

Título: Villancico a solo a los SS. Martyres con violines.

Forma musical: Villancico.

Género: Vocal-instrumental.

Tempo: Recitado. Aria, andante cómodo.

Tonalidad: La mayor.

Plantilla: Tiple solista, violín $1^{\circ}$, violín $2^{\circ}$, acompañamiento.

Letra:

Vivientes, qué fortuna! qué consuelo/ que con Ciriaco y Paula allá en el cielo/ tenéis dos protectores seguros,/ que son en defenderos fuertes muros:/ ya como luz la oscuridad deshacen/ y en abundantes lluvias satisfacen/ la sed ardiente con que el pueblo ruega/ con pecho humilde con creencia ciega:/ ya el esperado bien el cielo embía./ Alegría vivientes, alegría./ Fieles estad constantes,/ pues su favor y ayuda/ conseguís sin duda/ en todo mal sensible/ con tanta protección./ Ya os mirarán propicios/ quitando vuestras penas/ y dando a manos llenas/ los bienes que no impidan/ la eterna salvación. 
A.M.C.M. Pieza 207, 4.

Autor: Jaime Torrens.

Fecha: 1785.

Título: Villancico a 4 a los Stos. Mártires con violines.

Forma musical: Villancico.

Género: Vocal-instrumental.

Tempo: Estribillo, andante cómodo. Coplas, andante cómodo.

Tonalidad: Mi b mayor.

Plantilla: tiple $1^{\circ}$, tiple $2^{\circ}$, alto, tenor, violín $1^{\circ}$, violín $2^{\circ}$, trompa $1^{a}$, trompa $2^{a}$, acompañamiento.

Letra:

Ya Málaga alienta, su tierra se ensalza, / los fieles se alegran, florecen las plantas. / Ciriaco invencible, benéfica Paula, / sus bienes procuran, sus males espantan/ y en calles y templos sus plácemes cantan/ alegres los hombres con voz de alabanza. / Ya de la divina diestra mil bienes al pueblo bajan/ porque los Santos Patronos nunca olvidan a su patria. / Con su sangre nos dejaron la tierra santificada/ y a Dios piden que produzca los frutos con abundancia.

\section{A.M.C.M. Pieza 182, 1.}

Autor: Jaime Torrens.

Fecha: 1787.

Título: Aria de tenor a solo con violines a los Stos. Patronos.

Forma musical: Aria.

Género: vocal instrumental.

Tempo: Recitado, andante. Aria, andantino.

Tonalidad: Fa mayor.

Plantilla: Tenor solista, violín $1^{\circ}$, violín $2^{\circ}$, acompañamiento.

Letra:

Al impulso feroz del infame enojo/ Las piedras del tormento disparadas/ A Ciriaco y Paula dirigidas/ Del sacrílego monte son despojo/ Oh, víctimas humildes y sagradas /Que exponéis al martirio vuestras vidas/ Con cuyo fiel católico desvelo/ Sois de Málaga honor, gloria del Cielo!/ Atienda a vuestro suspiro poderoso/ Nuestro culto y obsequio fervorosos/ ¿mortales qué fortuna/ que en este hermoso cielo/ venere vuestro celo/ a Paula como luna/ y a Ciriaco como sol!/ Y ya que nuestra tierra/ Produjo tales luces/ Destruyan los capuces/ De tenebrosa guerra/ Que impide su esplendor.

A.M.C.M. Pieza 182, 2.

Autor: Jaime Torrens.

Fecha: 1787.

Título: Aria a solo de tiple a los Stos. Patronos con violines y trompas "Celebrad malagueños".

Forma musical: Aria. 
Género: Vocal instrumental.

Tempo: Recitado. Andante cómodo.

Tonalidad: Sol mayor.

Plantilla: Tiple solista, acompañamiento, violín $1^{\circ}$, violín $2^{\circ}$, trompa $1^{\mathrm{a}}$, trompa $2^{\mathrm{a}}$.

Letra:

Celebrad malagueños moradores, aplaudid habitantes de esta tierra de Ciriaco y Paula/ la brillante fe poderosa con que en fuerte guerra del gentilísimo ingrato los furores/ quebranta y queda de su ardor triunfante:/ ríndanle cultos y veneraciones sus patricios afectos corazones/ que aunque reinan felices en el Cielo no olvidarán jamás su patrio suelo/ Por más que la serpiente pretenda cautelosa, astuta y engañosa/ de nuestra fe constante la hermosa luz borrar:/ brama, suspira y gime de verse tan burlada/ pues nuestra fe alentada de exemplo soberano le llega a destrozar.

\section{A.M.C.M. Pieza 191, 14.}

Autor: Jaime Torrens.

Fecha: 1788.

Título: Villancico a los Stos. Mártires a 5 con violines y clarines.

Forma musical: Villancico.

Género: Vocal-instrumental.

Tempo: Estrivillo allegro. Coplas andante cómodo.

Tonalidad: Re mayor.

Plantilla: Tenor ( $1^{\circ}$ coro), tiple, alto, tenor, bajo $\left(2^{\circ}\right.$ coro), violín $1^{\circ}$, violín $2^{\circ}$, clarín $1^{\circ}$, clarín $2^{\circ}$, acompañamiento.

\section{Letra:}

El empíreo y la tierra,/ las flores y las plantas,/ el sol y la luna,/ el día y el alba,/ el ángel y el hombre,/ el volcán y el agua,/ aplaudan la victoria de Ciriaco y de Paula,/ pues vuelan al cielo hagámosle salva/ y en cantos sonoros celebren a coros/ la gloria que gozan el triunfo que ganan/ y alabe este pueblo la fe y la constancia/ de dos campeones en cruda batalla./ Con valor Ciriaco lucha, invicta pelea Paula/ ni a la fuerza se intimidan ni los vencen amenazas./ Llegan los dos al torrente donde sus dichosas almas/ al impulso de las piedras consiguen corona y palma.

A.M.C.M. Pieza $188,7$.

Autor: Jaime Torrens.

Fecha: 1790.

Título: Villancico a dúo a los Stos. Mártires San Ciriaco y Sta. Paula con violines.

Forma musical: Villancico.

Género: Vocal-instrumental.

Tempo: Recitado. Aria, andante cómodo.

Tonalidad: Si b mayor.

Plantilla: Tiple y tenor a dúo, violín $1^{\circ}$, violín $2^{\circ}$ y acompañamiento. 


\section{Letra:}

Ciriaco invicto, mártir esforzado,/ a quien adoración rendida he dado./Gloriosa Paula,/ protectora mía/ dulce embelezo del que en ti confía./ Qué intimidar podrá a tus protegidos/ debajo de tu amparo protegidos,/ qué avenida de penas de tormento/ no podrá detener tu valimiento,/ mas si vuestro favor es fuerte muro/ en él tu feliz pueblo está seguro./ Tú nos inspiras cuando fiel miras en nuestro mal./ Tú nos amparas cuando reparas en nuestro mal./ Dulce Ciriaco, tú al hombre flaco favor darás./Paula constante, tú al suplicante favor darás.

Si comparamos los villancicos de Torrens dedicados a los Patronos con el resto de la producción del mismo autor en éste género, observamos que prevalece la estructura "a la italiana", es decir, recitado-aria en comparación con la forma "tradicional" que consiste en la alternancia de estribillo y $\operatorname{coplas}^{78}$, siendo la única temática en que esto ocurre, pues en las demás (Navidad, Reyes, Concepción, Santísimo) es superior el número de villancicos que presentan la forma tradicional.

En cuanto a la plantilla instrumental, de los 12 villancicos de Torrens, seis son para dos violines y acompañamiento, sólo dos prevén el uso de clarines y los cuatro restantes requieren el uso de trompas, además de los violines tanto en este caso como en el anterior ${ }^{79}$. En último lugar, con relación a la disposición vocal, destacan los que son para una sola voz (tiple o tenor) o a dúo (tiple-alto, tiple-tenor) en número de siete frente a los cinco restantes cuya disposición canora es a 4, a 5 , a 6 y dos a 7.

\section{A.M.C.M. Pieza 130, 3.}

Autor: Eduardo Ocón y Rivas (1833-1901) organista $2^{\circ}$ intermitente y director ocasional de la capilla extravagante.

Fecha: sin año.

Título: Coplas a dúo a los Stos. Mártires Ciriaco y Paula.

Forma musical: Coplas.

Género: Vocal-instrumental.

Tempo: sin indicación.

Tonalidad: Fa M.

Plantilla: Sólo se conserva un papel suelto de bajo. Suponemos que, como mínimo, llevaría también acompañamiento.

\section{Letra:}

Pues por gracia sin igual

Fuisteis a Málaga dados

Libradnos, como abogados,

De la ira celestia/80.

78 Vid. MARTÍN QUIÑONES, op. cit., 470.

79 Ibíd. p. 510.

80 La letra no se puede reconstruir sólo a partir de la partitura conservada. Sin embargo, podemos conocerla gracias al libro de LÓPEZ GUIJARRO A., Novena de los Santos Mártires Ciriaco y Paula, Patronos de la ciudad 
$3^{\circ}$ El himno de D. Manuel Ruiz Castro.

Siendo párroco de la iglesia de los Mártires D. Luis Vera Ordás, encarga a D. Manuel Ruiz Castro, beneficiado maestro de capilla de la Catedral, un himno a los Patronos que pudiera ser cantado por el pueblo en el transcurso de las celebraciones en honor de dichos Santos. D. Manuel lo compone alrededor de 1950 con letra del mencionado D. Luis Vera Ordás, que llegaría a ser canónigo magistral. Según nos informa D. Manuel Gámez López, que por entonces era director de la Schola Cantorum del Seminario Diocesano, este himno era interpretado en el Seminario el día de los Patronos, es decir el 18 de junio. Sin que se sepa la suerte de este himno durante los años posteriores al traslado del Seminario a Granada a finales de los sesenta, con la consecuente desaparición de la Schola Cantorum, vemos que éste reaparece en los cultos eucarísticos de la parroquia de los Mártires, mantenidos por entonces por los hermanos de la Archicofradía de la Pasión de la misma parroquia.

Gracias al empeño del anterior hermano mayor de la Congregación, que facilita una grabación en cinta magnética del himno a D. Luis Díez Huertas, quien a su vez hace una primera trascripción "al dictado" de la cinta y recurre a seminaristas de entonces, sacerdotes hoy, que pudieron haberlo cantando en el seminario para que hagan una corrección de lo que Huertas había podido escribir, es como el himno ha podido ser finalmente recuperado y escrito, para evitar una posible pérdida definitiva.

Díez Huertas, movido por el cariño hacia D. Manuel Ruiz Castro, acomete no sólo la trascripción a una voz del himno, sino otra versión a voces mixtas del mismo, para poder ser cantado por una coral polifónica, otra versión polifónica para voces graves y, finalmente, una versión para banda de música, destinada al acompañamiento de las imágenes de los Patronos en las salidas procesionales.

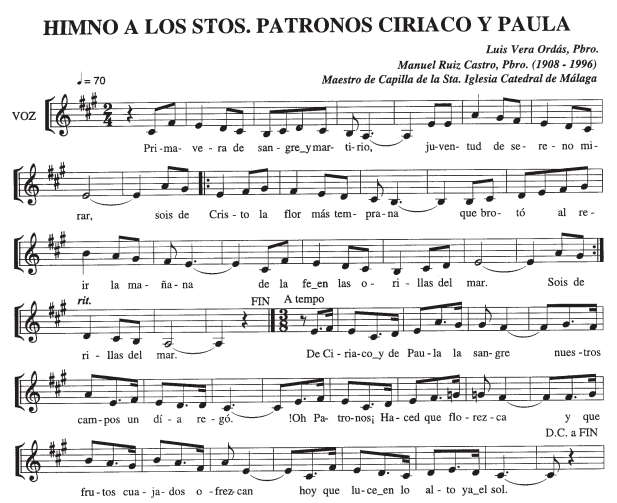

de Málaga. Málaga, 1830. También en SIMONET, op. cit., p. 73-76. 